\title{
RELATION BETWEEN DEGREE OF LIVER STIFFNESS AND DEVELOPMENT OF HEPATOCELLULAR CARCINOMA IN CHRONIC HEPATITIS C VIRUS PATIENTS
}

\author{
By \\ Mohamed Mahmoud El-Twab, Adel Abd El-Fattah El-Rakeeb, \\ Mohamad Kamal Al-Sharqawi* and Ahmed Mohamed Abo-Hassan \\ Departments of Internal Medicine and Diagnostic Radiology*, Faculty of Medicine, Al- \\ Azhar University
}

Corresponding author: Mohamed Mahmoud El-Twab, E-mail: meltwab88@gmail.com

\begin{abstract}
Background: Hepatocellular carcinoma is the fifth most common tumor worldwide and the second most common cause of cancer-related death. Hepatitis $\mathrm{C}$ virus $(\mathrm{HCV})$ infection is a leading cause of liver cirrhosis and hence the development of hepatocellular carcinoma (HCC). Egypt has the highest HCV prevalence worldwide. The introduction of new direct acting antiviral agents in the past 5 years has dramatically improved the outcomes of HCV treatment response with $>90 \%$ of patients achieving a sustained virological response (SVR) after 12 weeks of end treatment. However, the effect of direct-acting antivirals (DAAs) induced HCV clearance on HCC recurrence after HCC treatment has emerged as a topic of controversy.
\end{abstract}

Objective: To evaluate the relation between liver stiffness as measured by fibro scan and development of $\mathrm{HCC}$ in chronic $\mathrm{HCV}$ patients.

Patients and methods: A prospective study was done at Kafar Alshaykh National Hepatology Institute conducted in collaboration with the Gastroenterology Unit Department of Internal Medicine, Al-Hussein University Hospital, and Cairo Egypt. The study included 150 patients with proven liver cirrhosis secondary to chronic hepatitis $\mathrm{C}(\mathrm{CHC})$ they were further sub classified into three equal groups: Group I with chronic hepatitis C, liver cirrhosis and HCC, Group II with CHC and HCC that appeared after treatment with DAA, and Group III (control group) with cirrhotic chronic hepatitis C (CHC) without HCC.

Results: In this study, there was a statistically significant difference between group I ( $30.38 \pm 11.32 \mathrm{kPa})$ and controlled group $(25.0 \pm 13.34 \mathrm{kPa})$, regarding fibro scan results $(\mathrm{P}=0.004)$. On other hand there was no significant difference between group II $(23.24 \pm 7.69 \mathrm{kPa})$ and controlled group regarding LS.

Conclusion: Fibro scan can be a good technique for detection of HCC high-risk cirrhotic patients not treated by DAA and can be of great added value if incorporated in the current HCC screening protocols in hepatitis C cirrhotic patients. On the other hand, LS tended to decrease dramatically after the treatment with DAA. Using TE in these patients would therefore be misleading liver stiffness measurement (LSM), the risk of $\mathrm{HCC}$ remains because advanced fibrosis or cirrhosis, which is the most important risk factor for liver cancer, not completely resolved by antiviral treatment. As a matter of fact, the degree of liver fibrosis seems to be a strong predictor of the risk of HCC development.

Keywords: Liver Stiffness, Hepatocellular Carcinoma, Chronic Hepatitis C Virus.

\section{INTRODUCTION}

Chronic infection with hepatitis $\mathrm{C}$ virus (HCV) is considered one of the major causes of end-stage liver disease including cirrhosis and HCC (Patel et al., 2010). Hepatocellular carcinoma (HCC) is the 
most common primary malignancy of the liver and represents the third leading cause of cancer-related deaths worldwide (Park et al., 2015).

Progressive hepatic fibrosis with the development of cirrhosis is a feature of almost all chronic liver diseases. The most common cause of chronic liver disease is hepatitis $\mathrm{C}$ virus (HCV), approximately $10-20 \%$ of patients with chronic HCV infection have cirrhosis at first clinical presentation, and $20-30 \%$ of those who do not have cirrhosis will eventually develop this condition and its complications within one or more decades. These complications are liver failure, ascites, variceal bleeding, portal-systemic encephalopathy, and hepatocellular carcinoma (HCC) (Badr et al., 2016). HCC is one of the serious complications of chronic HCV infection, and the risk is increased with advancing hepatic fibrosis and cirrhosis reaching an incidence of about $3.5 \%$ in cirrhotic patients per year (Conti et al., 2016).

In Egypt, the prevalence of hepatocellular carcinoma increased markedly in the last decade due to the high prevalence of hepatitis $\mathrm{C}$ virus and the improved survival for cirrhotic patients allowing time for some of them to develop HCC (Abd-Elsalam et al., 2018). For improvement in the fate of liver cancer, adequate treatment after early detection is important. To this end, it is critical to identify high-risk groups for liver cancer and to conduct appropriate screening in the clinical practice of chronic liver disease (Zacharakis et al., 2018).

Liver cirrhosis has been evaluated by liver biopsy, as the histology is the gold standard for quantitative fibrosis assessment; but liver biopsy is associated with several problems such as invasiveness, sampling errors, and diagnostic differences between pathologists. This makes it unpopular among patients and impractical for serial assessments of patients with chronic liver disease. With the development of Fibroscan using transient elastography, it became possible to estimate the elasticity of the liver. An accurate quantification of the degree of liver fibrosis is necessary for prognosis and guiding surveillance (Chin et al., 2016).

The accuracy of Fibro scan diagnosis of cirrhosis has been widely recognized in many chronic liver diseases except for some liver conditions such as congestion, severe infections, or cholestasis, which may be over estimating cirrhosis with Fibro scan (Kim et al., 2011). The risk of liver cancer was assessed based on liver stiffness measured by Fibro scan among the European population (Adler et al., 2016). However, in most reports, the risk of liver cancer has been indirectly assessed based on the value of cirrhosis as measured by Fibro scan; however, HCC associated liver stiffness was not directly assessed (Pesce et al., 2012). Additionally, the effectiveness of Fibro scan in predicting the risk of HCC has not been fully elucidated.

The aim of this work was to evaluate relation between stage of liver stiffness as measured by fibro scan and development of HCC in chronic HCV patients.

\section{PATIENTS AND METHODS}

A prospective study was done at Kafar Alshaykh National Hepatology Institute conducted in collaboration with the 
Gastroenterology Unit at the Department of Internal Medicine, Al-Hussein University Hospital, Cairo, Egypt.

The study included 150 patients with proven liver cirrhotic secondary to chronic hepatitis $\mathrm{C}(\mathrm{CHC})$. They were further sub classified into three equal groups: Group I with chronic hepatitis $\mathrm{C}$, liver cirrhosis and HCC, Group II with CHC and HCC that appeared after treated with DAA, and Group III (control group) with cirrhotic chronic hepatitis $\mathrm{C}(\mathrm{CHC})$ without HCC.

\section{Exclusion Criteria:}

- HCV patients received antiviral regimens containing interferon.

- HCV patients co-infected with HBV and HIV.

- HCV patients with baseline body mass index $(\mathrm{BMI})>35 \mathrm{~kg} / \mathrm{m} 2$.

- $\mathrm{HCV}$ patients with ascites. (Contraindication for fibro scan).

- Alcoholics and/or intravenous drug abusers and diabetics.

\section{Ethical consent:}

An approval of the study was obtained from Al- Azhar University academic and ethical committee. Every patient signed an informed written consent for acceptance of the operation.

\section{All eligible patients informed regarding all procedures and they were subjected to the following:}

1. History talking: General examination and local examination

\section{Laboratory investigations:}

- $\mathrm{CBC}$.

- Liver function tests: Serum bilirubin (total and direct), serum albumin, PT, PC, INR, AST, ALT

and alkaline phosphatase.

- Renal functions tests: Urea, creatinine and estimated GFR.

- Viral markers: HBsAg and HCVAb and HIVAb.

- Alpha feto protein.

\section{HCV-RNA was assessed by PCR.}

\section{Imaging:}

- Abdominal ultrasonography: Abdominal ultrasonography was performed to all patients. Comments were made on the size of the liver, smoothness of its surface, its texture, portal vein diameter, hepatic veins and presence of periportal fibrosis.

- Computed topography (C.T): Triphasic spiral CT scan with double contrast was done to all patients in the HCC group for the diagnosis of hepatic focal lesions with specific features of HCC.

- Transient elastography: Each of the 150 patients was subjected to liver stiffness measuring using the transient elastogrpahy machine "Fibro scan" manufactured by Echosens For assessment degree of fibrosis (F0-F4).

\section{Statistical analysis:}

Data were fed to the computer and analyzed using IBM SPSS software package version 20.0. (Armonk, NY: IBM Corp) Qualitative data were described using number and percent. The Kolmogorov-Smirnov test was used to verify the normality of distribution Quantitative data were described using 
range (minimum and maximum), mean, standard deviation, median and interquartile range (IQR). Significance of the obtained results was judged at the 5\% level. Chi-square test for categorical variables, to compare between different groups. F-test (ANOVA) for normally distributed quantitative variables, wes used to compare between more than two groups, and Post Hoc test (Tukey) for pairwise comparisons. Kruskal Wallis test for abnormally distributed quantitative variables was used to compare between more than two studied groups, and Post Hoc (Dunn's multiple comparisons test) for pairwise comparisons. P-value $<0.05$ was considered significant.

\section{RESULTS}

Mean age within group I was $59.68 \pm$ 8.37 years, in Group II was $56.66 \pm 8.34$ years, while in group III was $56.62 \pm 6.96$ thus showing no statistical difference
( $p>0.05$ ) The male: female ratio was 35: 15 in group I compared to 40: 10 in Group II, and Group III was 42: 8, showing no statistical difference $(\mathrm{p}>0.05)$ (Table 1).

Table (1): Comparison between the three studied groups according to demographic data

\begin{tabular}{|c|c|c|c|c|c|c|c|}
\hline \multirow[t]{2}{*}{$\begin{array}{l}\text { Groups } \\
\text { Parameters }\end{array}$} & \multicolumn{2}{|c|}{$\begin{array}{l}\text { Group I } \\
(\mathbf{n}=\mathbf{5 0})\end{array}$} & \multicolumn{2}{|c|}{$\begin{array}{c}\text { Group II } \\
(\mathbf{n}=\mathbf{5 0})\end{array}$} & \multicolumn{2}{|c|}{$\begin{array}{l}\text { Control } \\
(\mathbf{n}=\mathbf{5 0})\end{array}$} & \multirow{2}{*}{$\begin{array}{c}\mathbf{P} \\
\text { Value }\end{array}$} \\
\hline & No. & $\%$ & No. & $\%$ & No. & $\%$ & \\
\hline \multicolumn{8}{|l|}{ Sex: } \\
\hline Male & 35 & 70.0 & 40 & 80.0 & 42 & 84.0 & \multirow{2}{*}{0.220} \\
\hline Female & 15 & 30.0 & 10 & 20.0 & 8 & 16.0 & \\
\hline \multicolumn{8}{|l|}{ Age (years): } \\
\hline Min. - Max. & \multicolumn{2}{|c|}{$39.0-80.0$} & \multicolumn{2}{|c|}{$43.0-77.0$} & \multicolumn{2}{|c|}{$40.0-73.0$} & \multirow{3}{*}{0.089} \\
\hline Mean \pm SD & \multicolumn{2}{|c|}{$59.68 \pm 8.37$} & \multicolumn{2}{|c|}{$56.66 \pm 8.34$} & \multicolumn{2}{|c|}{$56.62 \pm 6.96$} & \\
\hline Median (IQR) & \multicolumn{2}{|c|}{$58.0(55.0-65.0)$} & \multicolumn{2}{|c|}{$57.0(50.0-62.0)$} & \multicolumn{2}{|c|}{$57.0(51.0-60.0)$} & \\
\hline
\end{tabular}


There was a significant decrease in platelet counts in HCC patients without treatment $(97.82 \pm 35.56)$ from other groups. There was no statistically significant difference between HCC patients after treatment and controlled groups regarding Platelets counts. There was a statistically significant difference between group 1 and group II regarding creatinine $(\mathrm{p}$ value $\leq 0.05)$. There was statistically significant difference between group II and control group regarding creatinine ( $\mathrm{p}$ value $>0.05$ ). There was no statistically significant difference between group 1 group II and control group regarding urea $(\mathrm{p}$ value $>0.05)$ (Table 2$)$.

Table (2): Comparison between the three studied groups according to $\mathrm{CBC}$ and renal function

\begin{tabular}{|c|c|c|c|c|}
\hline $\begin{array}{l}\text { Groups } \\
\text { Parameters }\end{array}$ & $\begin{array}{l}\text { Group I } \\
(\mathbf{n}=\mathbf{5 0})\end{array}$ & $\begin{array}{c}\text { Group II } \\
(\mathbf{n}=\mathbf{5 0})\end{array}$ & $\begin{array}{l}\text { Control } \\
(\mathbf{n}=\mathbf{5 0})\end{array}$ & P Value \\
\hline \multicolumn{5}{|l|}{$\begin{array}{l}\text { CBC: } \\
\mathrm{Hb}\end{array}$} \\
\hline Min. - Max. & $7.90-14.40$ & $6.60-15.20$ & $7.90-17.0$ & \multirow{3}{*}{0.025} \\
\hline Mean \pm SD. & $10.75 \pm 1.79$ & $11.76 \pm 1.96$ & $10.92 \pm 2.13$ & \\
\hline Median (IQR) & $\begin{array}{c}10.20(9.30- \\
12.30)\end{array}$ & $\begin{array}{c}11.70(10.40- \\
13.10)\end{array}$ & $\begin{array}{c}10.20(9.30- \\
12.30)\end{array}$ & \\
\hline Sig. bet. grps. & \multicolumn{4}{|c|}{$\mathrm{p}_{1}=0.030^{*}, \mathrm{p}_{2}=0.906, \mathrm{p}_{3}=0.084$} \\
\hline \multicolumn{5}{|l|}{ PLT } \\
\hline Min. - Max. & $22.0-160.0$ & $10.70-900.0$ & $66.0-234.0$ & \multirow{3}{*}{0.001} \\
\hline Mean \pm SD. & $97.82 \pm 35.56$ & $159.3 \pm 127.6$ & $136.0 \pm 39.63$ & \\
\hline Median (IQR) & $\begin{array}{c}87.0(76.0- \\
130.0)\end{array}$ & $\begin{array}{c}136.0(90.0- \\
187.0)\end{array}$ & $\begin{array}{c}135.0(115.0- \\
153.0)\end{array}$ & \\
\hline Sig. bet. grps. & \multicolumn{4}{|c|}{$\mathrm{p}_{1}=0.001^{*}, \mathrm{p}_{2}=0.047^{*}, \mathrm{p}_{3}=0.315$} \\
\hline \multicolumn{5}{|l|}{ WBCs } \\
\hline Min. - Max. & $1.90-32.0$ & $4.0-13.0$ & $2.80-13.70$ & \multirow{3}{*}{0.010} \\
\hline Mean \pm SD. & $6.83 \pm 5.12$ & $6.90 \pm 2.31$ & $5.63 \pm 2.19$ & \\
\hline Median (IQR) & $6.35(3.60-8.0)$ & $6.50(5.0-8.0)$ & $5.10(4.10-6.30)$ & \\
\hline Sig. bet. grps. & \multicolumn{4}{|c|}{$\mathrm{p}_{1}=0.068, \mathrm{p}_{2}=0.229, \mathrm{p}_{3}=0.002^{*}$} \\
\hline \multicolumn{5}{|l|}{$\begin{array}{l}\text { Renal function: } \\
\text { Serum Creatinine }\end{array}$} \\
\hline Min. - Max. & $0.30-2.30$ & $0.50-2.10$ & $0.50-2.50$ & \multirow{3}{*}{0.015} \\
\hline Mean \pm SD. & $1.23 \pm 0.42$ & $1.05 \pm 0.37$ & $1.23 \pm 0.44$ & \\
\hline Median (IQR) & $1.25(0.90-1.50)$ & $1.0(0.80-1.23)$ & $1.25(0.90-1.50)$ & \\
\hline Sig. bet. grps. & \multicolumn{4}{|c|}{$\mathrm{p}_{1}=0.011^{*}, \mathrm{p}_{2}=0.935, \mathrm{p}_{3}=0.014^{*}$} \\
\hline Urea & & & & \multirow{4}{*}{0.450} \\
\hline Min. - Max. & $21.0-78.0$ & $13.0-80.0$ & $21.0-78.0$ & \\
\hline Mean \pm SD. & $35.52 \pm 15.35$ & $37.92 \pm 11.60$ & $38.48 \pm 9.57$ & \\
\hline Median (IQR) & $\begin{array}{c}29.50(25.0- \\
44.0)\end{array}$ & $\begin{array}{c}36.0(32.0- \\
44.0)\end{array}$ & $37.0(33.0-42.0)$ & \\
\hline
\end{tabular}

$\mathrm{p}: \mathrm{p}$ value for comparing between the studied groups $\mathrm{p} 1$ : $\mathrm{p}$ value for comparing between group I and group II

p2: $p$ value for comparing between group I and control p3: $p$ value for comparing between group II and control 
Serum alanine aminotransferase levels (ALT) were significantly lower in patient with HCC After treatment $(34.26 \pm 12.69)$ compared to HCC patients without treatment $(55.60 \pm$ 25.12). Serum aspartate aminotransferase levels (AST) were significantly lower in patient with HCC after treatment (42.94 \pm 17.80) compared to HCC patients without treatment $(55.18 \pm 30.73)$. There were statistical significant difference between groups regarding albumin level, which decreased in HCC patient without treatment. There was a statistically significant difference between HCC patient (group 1, II) and control group regarding Feto protein ( $\mathrm{p}$ value $>0.05$ ) (Table 3).

Table (3): Comparison between the three studied groups according to liver function and alpha feto protein

\begin{tabular}{|c|c|c|c|c|}
\hline $\begin{array}{l}\text { Groups } \\
\text { Parameters }\end{array}$ & $\begin{array}{l}\text { Group I } \\
(n=50)\end{array}$ & $\begin{array}{c}\text { Group II } \\
(\mathbf{n}=\mathbf{5 0})\end{array}$ & $\begin{array}{l}\text { Control } \\
(\mathrm{n}=50)\end{array}$ & $\begin{array}{c}\mathbf{P} \\
\text { Value }\end{array}$ \\
\hline \multicolumn{5}{|l|}{ Liver function: } \\
\hline Min. - Max. & $33.0-169.0$ & $13.0-66.0$ & $16.0-118.0$ & \multirow{3}{*}{$<0.001$} \\
\hline Mean \pm SD. & $55.60 \pm 25.12$ & $34.26 \pm 12.69$ & $47.64 \pm 18.33$ & \\
\hline Median (IQR) & $48.50(40.0-59.0)$ & $35.0(26.0-42.0)$ & $\begin{array}{c}44.50(35.0- \\
57.0)\end{array}$ & \\
\hline Sig. bet. grps. & \multicolumn{4}{|c|}{$\mathrm{p}_{1}<0.001, \mathrm{p}_{2}=0.074, \mathrm{p}_{3}<0.001$} \\
\hline \multicolumn{5}{|l|}{ AST (U/L) } \\
\hline Min. - Max. & $26.0-190.0$ & $16.0-84.0$ & $16.0-90.0$ & \multirow{3}{*}{0.011} \\
\hline Mean \pm SD. & $55.18 \pm 30.73$ & $42.94 \pm 17.80$ & $40.88 \pm 17.94$ & \\
\hline Median (IQR) & $46.0(36.0-63.0)$ & $40.50(30.0-55.0)$ & $\begin{array}{c}36.50(29.0- \\
52.0)\end{array}$ & \\
\hline Sig. bet. grps. & \multicolumn{4}{|c|}{$\mathrm{p}_{1}=0.031, \mathrm{p}_{2}=0.004, \mathrm{p}_{3}=0.471$} \\
\hline \multicolumn{5}{|l|}{ Serum albumin } \\
\hline Min. - Max. & $1.70-4.50$ & $1.50-4.90$ & $2.50-4.90$ & \multirow{3}{*}{$<0.001$} \\
\hline Mean \pm SD. & $2.57 \pm 0.60$ & $3.17 \pm 0.66$ & $3.49 \pm 0.63$ & \\
\hline Median (IQR) & $2.50(2.10-2.90)$ & $3.25(2.70-3.60)$ & $3.50(2.90-4.0)$ & \\
\hline Sig. bet. grps. & \multicolumn{4}{|c|}{$\mathrm{p}_{1}<0.001, \mathrm{p}_{2}<0.001, \mathrm{p}_{3}=0.035$} \\
\hline \multicolumn{5}{|l|}{ Alpha feto protein: } \\
\hline Min. - Max. & $2.60-5192.0$ & $2.09-964.0$ & $1.70-15.0$ & $<0.001$ \\
\hline Mean \pm SD & $541.2 \pm 855.1$ & $205.2 \pm 222.9$ & $3.31 \pm 1.99$ & \\
\hline Median (IQR) & $390.0(44.0-660.0)$ & $154.8(8.54-336.0)$ & $2.88(2.50-3.44)$ & \\
\hline Sig. bet. grps. & \multicolumn{4}{|c|}{$\mathrm{p}_{1}=0.022, \mathrm{p}_{2}<0.001^{*}, \mathrm{p}_{3}<0.001$} \\
\hline
\end{tabular}

$\mathrm{p}: \mathrm{p}$ value for comparing between the studied groups

$\mathrm{p} 1$ : $\mathrm{p}$ value for comparing between group I and group II

$\mathrm{p} 2$ : $\mathrm{p}$ value for comparing between group I and control

p3: $p$ value for comparing between group II and control 
There was no statistical significant difference between group 1 group II and control group regarding INR ( $\mathrm{p}$ value > 0.05). The mean liver stiffness measurement (LSM) Showed elevation in HCC patients without treatment (30.38 \pm 11.32) from controlled group (25.0 \pm 13.34). The mean liver stiffness measurement (LSM) showed no significant group $1 \mathrm{HCC}$ patients after treatment $(23.24 \pm 7.69)$ compared to controlled group (25.0 \pm 13.34). On comparison between groups and control group, there was no significant difference between groups regarding CAP (Table 4).

Table (4): Comparison between the three studied groups according to INR and Fibroscan results (Elastography and Controlled Attenuation Parameter (CAP)

\begin{tabular}{|c|c|c|c|c|}
\hline & $\begin{array}{l}\text { Group I } \\
(\mathbf{n}=50)\end{array}$ & $\begin{array}{c}\text { Group II } \\
(\mathbf{n}=\mathbf{5 0})\end{array}$ & $\begin{array}{l}\text { Control } \\
(\mathbf{n}=\mathbf{5 0})\end{array}$ & P Value \\
\hline $\begin{array}{l}\text { INR: } \\
\text { Min. - Max. }\end{array}$ & $0.90-2.07$ & $0.90-2.40$ & $0.90-2.07$ & \multirow{3}{*}{0.981} \\
\hline Mean \pm SD & $1.39 \pm 0.32$ & $1.38 \pm 0.36$ & $1.39 \pm 0.33$ & \\
\hline Median (IQR) & $1.39(1.09-1.67)$ & $1.34(1.09-1.64)$ & $1.40(1.08-1.70)$ & \\
\hline \multicolumn{5}{|c|}{ Elastography and CAP: } \\
\hline E (Kpa) & & & & \multirow{4}{*}{0.004} \\
\hline Min. - Max. & $14.0-63.90$ & $10.40-38.0$ & $13.0-68.0$ & \\
\hline Mean \pm SD & $30.38 \pm 11.32$ & $23.24 \pm 7.69$ & $25.0 \pm 13.34$ & \\
\hline Median (IQR) & $27.50(22.3-37.9)$ & $22.0(17.0-28.0)$ & $20.90(17.3-27.7)$ & \\
\hline Sig. bet. grps. & \multicolumn{4}{|c|}{$\mathrm{p}_{1}=0.004^{*}, \mathrm{p}_{2}=0.120, \mathrm{p}_{3}=0.426$} \\
\hline CAP & & & & \multirow{4}{*}{0.147} \\
\hline Min. - Max. & $100.0-350.0$ & $132.0-317.0$ & $100.0-400.0$ & \\
\hline Mean \pm SD. & $209.3 \pm 61.29$ & $214.4 \pm 57.97$ & $232.0 \pm 61.87$ & \\
\hline Median (IQR) & $\begin{array}{c}203.0(173.0- \\
252.0)\end{array}$ & $\begin{array}{c}194.0(163.0- \\
268.0)\end{array}$ & $\begin{array}{c}223.0(184.0- \\
270.0)\end{array}$ & \\
\hline
\end{tabular}

$\mathrm{p}$ : $\mathrm{p}$ value for comparing between the studied groups $\mathrm{p} 1$ : $\mathrm{p}$ value for comparing between group I and group II $\mathrm{p} 2$ : $\mathrm{p}$ value for comparing between group I and control p3: $\mathrm{p}$ value for comparing between group II and control

\section{DISCUSSION}

In the current study, $\mathrm{HCC}$ was commonly presented in males $(75 \%)$ more than in females $(25 \%)$. This was in agreement with Bosch et al. (2010) who reported that HCC predominantly affects males with incidence two to four times more common in males than females. $E l$ Kassas et al. (2018) and Ebrahim et al. (2020) reported that males to female's predominance is greater than 2:1 among their studied HCC patient.
In Egypt, HCC ranks the second and the sixth cancer in men and women, respectively (Omar et al., 2013).

In this study, patient with HCC had the mean age of group $1(59.68 \pm 8.37)$ years, while in Group II was (56.66 \pm 8.34$)$ years, thus showing no statistical difference. This was in agreement with Yang et al. (2016) who found that, the age at onset of $\mathrm{HCV}$-induced hepatocellular carcinoma was significantly different between African countries. 
In the current study, AFP in cases of liver cancer (HCC) had an average value of $541.2 \mathrm{ng} / \mathrm{ml}$ in group 1 while in group average value of $205.2 \mathrm{ng} / \mathrm{ml}$ which was statistically higher than patients with cirrhosis $(3.31 \mathrm{ng} / \mathrm{ml})$. These results were in agreement with Jiang et al. (2011) who reported that AFP in cases of liver cancer had an average value of $384.6 \mathrm{ng} / \mathrm{ml}$ which was statistically higher than patients with cirrhosis $(26.04 \mathrm{ng} / \mathrm{ml})$.

On the other hand, other studies have shown that the role of AFP in diagnosing liver cancer is limited, and these results were supported by El-Serag et al. (2011) who stated that AFP was not elevated in all patients with liver cancer. Its sensitivity to detect liver cancer is $79 \%$; the specificity is also $89 \%$ and not $100 \%$ because AFP in the serum can also be detected in patients with cirrhosis and chronic hepatitis. Huaibin et al. (2012) also concluded that the $\alpha$-fetoprotein (AFP) level in the blood was a poor diagnostic indicator in liver cancer patients.

Our data reported that transient elastography (TE) may be a useful and promising noninvasive method for liver fibrosis assessment and it is a good diagnostic predictor for HCC development in $\mathrm{HCV}$ cirrhotic patients. In the present study, there was a significant difference between both groups regarding liver Stiffness. Patients with proven cirrhotic chronic hepatitis $\mathrm{C}$ (CHC) with $\mathrm{HCC}$ showed a significant higher Stiffness than control group.

This was in agreement with Singh et al. (2013) reported that the degree of liver stiffness was associated with risk of decompensated cirrhosis, HCC, and death in patients with chronic liver diseases (CLDs). Liver stiffness measurement (LSM) therefore might be used in risk stratification. Tatsumi et al. (2015) reported liver stiffness measurement in their work for risk assessment of hepatocellular carcinoma and found that in $\mathrm{HCV}$, liver stiffness of more than 12.0 $\mathrm{kPa}$ was an independent risk factor for new HCC development. Collectively, determining the fibrotic cutoff values for HCC concurrence would be important in evaluating HCC risks.

Ebrahim et al. (2020) reported cutoff, value of $24 \mathrm{kPa}$ for diagnostic prediction of HCC with sensitivity $100 \%$, specificity 83.3\%, PPV 94.5\%, NPV $77.3 \%$, and AUC 89\%. As regards binary logistic regression for predictors of $\mathrm{HCC}$, Child $\mathrm{C}$, AST, Fibro scan, and AFP were predictors for developing HCC.

In this study, there was marked decrease in liver stiffness in group II HCC patients after treatment from group I HCC patients without treatment, although LSM improved in patient after treatment. The risk of HCC remained because of advanced fibrosis or cirrhosis, which is the most important risk factor for liver cancer, is not completely resolved by antiviral treatment. As a matter of fact, the degree of liver fibrosis seems to be a strong predictor of the risk of HCC development.

\section{Several studies support that DAA decreased LS:}

The median time between end of treatment and post-treatment TE measurement was 16.1 weeks. In this relatively short time after $\mathrm{HCV}$ eradication, a median decrease in TE values of over $30 \%$ was observed in the 
group achieving SVR (Bachofner et al., 2016).

LS decreased at a rate of $8.1 \%$ per year in those who achieved sustained virological responses, but increased at $0.1 \%$ per year in those who could not achieve sustained virological response instead of antiviral therapy, and increased at $3.7 \%$ per year in those who did not undergo antiviral therapy (Nakagomi et al., 2018).

Pan et al. (2018) found that most of the patients whose LSM improved during follow-up still had advanced fibrosis or cirrhosis in liver biopsies. However, they found substantial differences between both pre- and post-SVR biopsies: (1) there was an improvement in liver inflammation in $73 \%$ of patients, and (2) there was improvement in sinusoidal fibrosis. The latter was also demonstrated by morphometric analysis showing a reduction in the total amount of collagen.

Fernandes et al. (2019) demonstrated that at least $30 \%$ of LSM reduction was used as a threshold indicative of clinically relevant fibrosis regression after SVR.

Martinez et al. (2019) stated that $70 \%$ of patients had decrease of liver stiffness measurement $(\mathrm{LSM})<10 \mathrm{kPa}$ after SVR, but still had at least bridging fibrosis in liver histology.

HCV treatment outcomes significantly improved after the introduction of new DAAs in the past few years with a response of $>90 \%$ of patients achieving an SVR after 12 weeks of starting treatment (Liovet and Villanueva, 2016).

The increased success in $\mathrm{HCV}$ treatment has raised the hope in a significant decrease in the rate of $\mathrm{HCC}$ occurrence and even its recurrence after treatment of neoplastic lesions (Conti et al., 2016).

In patients without cirrhosis, the incidence of HCC after DAA-induced SVR is very low ( 0.24 to 0.34 per 100 patient-years) (Ioannou et al., 2017 and Kanwal et al., 2017).

Given the low incidence of HCC in this population, current guidelines do not recommend HCC surveillance after SVR in patients who have not developed advanced fibrosis by the start of DAA therapy (European Association for the Study of the Liver, 2018).

In contrast, patients with pre-existing cirrhosis have a substantial HCC risk even after SVR. Among VA patients with cirrhosis who achieve SVR with DAA regimens, the annual incidence of $\mathrm{HCC}$ was $1.82 \%$. Although antiviral therapy reduces the risk of $\mathrm{HCC}$, the incidence of HCC is not completely eliminated. Patients with cirrhosis in particular remain at high risk of HCC. In both VA studies, patients with HCV-related cirrhosis had a higher incidence of HCC post- SVR than patients without cirrhosis (Kanwal et al., 2017).

Reig et al. (2016) demonstrated an HCC recurrence rate of $27.6 \%$ in 58 DAA treated patients included in their study. This result was significantly higher than that of the non-treated patients, supported by their observations of other studies. Conti et al. (2016), introduced results that matched with Reig et al. (2016), concerning HCC recurrence rates where they demonstrated a recurrence rate of $28.8 \%$ in 59 DAA treated patients during 24 weeks of post-treatment follow-up. 
El Kassas et al. (2018) found that $37.7 \%$ recurrence after a median of 16.0 months of follow-up. They observed a $25.4 \%$ HCC recurrence after a median of 23.0 months of follow-up.

\section{CONCLUSION}

Fibro scan can be a good technique for detection of HCC high-risk cirrhotic patients and can be of great added value if incorporated in the current HCC screening protocols in hepatitis $\mathrm{C}$ cirrhotic patients without treatment with DAA. On the other hand, LS tended to decrease dramatically after the treatment with DAA. Using TE in these patients would be a misleading liver stiffness measurement (LSM).

Although LSM improved in patients after treatment, the risk of HCC remained because advance fibrosis or cirrhosis, which was the most important risk factor for liver cancer, not completely resolved by antiviral treatment.

HCV patients did not receive directacting antiviral therapy had a greater risk of HCC occurrence.

\section{REFERENCES}

1. Abd-Elsalam $\mathrm{S}$, Elwan $\mathrm{N}$ and Soliman H. (2018): Epidemiology of liver cancer in Nile delta over a decade: a single-center study. South Asian J Cancer, 7: 24-26.

2. Adler $M$, Larocca $L$ and Trovato FM. (2016): Evaluating the risk of hepatocellular carcinoma in patients with prominently elevated liver stiffness measurements by FibroScan: a multicentre study. HPB (Oxford), 18(8):678-683.

3. Bachofner JA, Valli PV, Kröger A, Bergamin I, Künzler P, Baserga A,
Braun D, Seifert B, Moncsek A, Fehr J, Semela D, Magenta L, Müllhaupt B, Terziroli BerettaPiccoli B and Mertens JC. (2016): Direct antiviral agent treatment of chronic hepatitis $\mathrm{C}$ results in rapid regression of transient elastography and fibrosis markers fibrosis-4 score and aspartate aminotransferase-platelet ratio index. Liver Int., 37(3):369-376.

4. Badr RS, Korah AE, Tawfeek AR and Mohamed KA. (2016): A study on how patients catch hepatitis C virus. Menoufia Med J., 29:215-221.

5. Bosch FX, Ribes $J$ and Diaz $M$. (2010): Primary liver cancer: worldwide incidence and trends. Gastroenterology, 127: 5-16.

6. Chin JL, Pavlides M and Moolla A. (2016): Non-invasive markers of liver fibrosis: adjuncts or alternatives to liver biopsy? Front Pharmacol., 7:159163.

7. Conti F, Buonfiglioli F, Scuteri A, Crespi C, Bolondi L, Caraceni P, Foschi FG, Lenzi M, Mazzella G, Verucchi G, Andreone $P$ and Brillanti S. (2016): Early occurrence and recurrence of hepatocellular carcinoma in $\mathrm{HCV}$-related cirrhosis treated with direct-acting antivirals. J Hepatol. 65(4):727-733.

8. Ebrahim AE, Shehata MAH, Abousaif S, Hamisa MF, Abd-Elsalam S and Yousef M. (2020): Role of Fibroscan for early detection of hepatocellular carcinoma (HCC) in hepatitis $\mathrm{C}$ cirrhotic patients. Egyptian Journal of Radiology and Nuclear Medicine, 51:134-140. 
9. El Kassas M, Funk AL, Salaheldin $M$, Shimakawa $Y$, Eltabbakh $M$ and Jean K. (2018): Increased recurrence rates of hepatocellular carcinoma after DAA therapy in a hepatitis C-infected Egyptian cohort: a comparative analysis. J Viral Hepat., 25(6):623630.

10. El-Serag HB, Marrero JA and Rudolph E. (2011): Diagnosis and treatment of hepatocellular carcinoma. Gastroenterology, 134(6):1752-1763.

11. European Association for the Study of the Liver (2018): EASL clinical practice guidelines: management of hepatocellular carcinoma. J Hepatol., 69(1):182-236.

12. Fernandes FF, Piedade J, Guimaraes L, Nunes EP, Chaves U, Goldenzon RV, Cardoso SW, Duarte J, Grinsztejn B, Veloso VG, Pereira $G$ and Perazzo H. (2019): Effectiveness of direct acting agents for hepatitis $\mathrm{C}$ and liver stiffness changing after sustained virological response. J Gastroenterol Hepatol., 34(12):2187-2195.

13. Huaibin M, Hernandez-Prera JC, Zhu H, Dikman SH, Sidhu HK, Ward SC and Thung SN. (2012): Morphologic features of extrahepatic manifestations of hepatitis $\mathrm{C}$ virus infection. Clin Dev Immunol., 12: 3845 .

14. Ioannou GN, Green PK and Berry K. (2017): HCV eradication induced by direct-acting antiviral agents reduces the risk of hepatocellular carcinoma. J Hepatol., 5: 168-173.

15. Jiang J, Wu C, Shen Y, Xu B, Zheng $X$ and $L i ~ X$ and $X u$ N. (2011):
Clinical application of determining serum AFP-IgM complexes for diagnosis of small hepatocellular carcinoma. Anticancer Res., 31(2):687-691.

16. Kanwal F, Kramer J, Asch SM, Chayanupatkul M, Cao $\mathrm{Y}$ and ElSerag HB (2017): Risk of Hepatocellular Cancer in $\mathrm{HCV}$ Patients Treated With Direct-Acting Antiviral Agents. Gastroenterology, 153 (4):996-1005.

17. Kim JE, Ryoo BY and Ryn MH. (2011): Sorafenib for hepatocellular carcinoma according to Child-Pugh class of liver function. Cancer Cheomother. Pharmacol., 68:12851290.

18. Liovet JM and Villanueva A (2016): Effect of $\mathrm{HCV}$ clearance with direct acting antiviral agents on HCC. Nature Reviews Gastroenterology \& Hepatology, 13: 561-562.

19. Martínez JC, Puig SB, Delgado MP and Teresa M. (2019): Transient elastography in DAA era. Relation between post SVR LSM and histology. JVH, 4: 453-455.

20. Nakagomi R, Tateishi R, Masuzaki $R$ and Soroida Y. (2018): Liver stiffness measurements in chronic hepatitis C: Treatment evaluation and risk assessment. $\mathrm{J}$ Gastroenterol Hepatol., 34(5):921-928.

21. Omar A, Abou-Alfa GK, Khairy A and Omar H. (2013): Risk factors for developing hepatocellular carcinoma in Egypt. Chin Clin Oncol., 4: 43-49.

22. Pan JJ, Bao F and Du E. (2018): Morphometry confirms fibrosis 
regression from sustained virologic response to direct-acting antivirals for hepatitis C. Hepatol Commun., 2(11):1320-1330.

23. Park JW, Chen M, Colombo M, Roberts LR, Schwartz M, Chen PJ, Kudo M, Johnson P, Wagner S, Orsini LS and Sherman M. (2015): Global patterns of hepatocellular carcinoma management from diagnosis to death: the BRIDGE Study. Liver Int., 35(9):2155-66.

24. Patel K, Nelson DR, Rockey DC, Afdhal NH, Smith KM, Oh E, Hettinger $K$, Vallee $M$, Dev A, Smith-Riggs $M$ and McHutchison JG (2010): Correlation of FIBROSpect II with histologic and morphometric evaluation of liver fibrosis in chronic hepatitis C. Clinical Gastroenterology and Hepatology, 6: 242-247.

25. Pesce A, Scilletta $R$ and Branca A. (2012): Does transient elastography (FibroScan ${ }^{\circledR}$ ) have a role in decision making in hepatocellular carcinoma? HPB (Oxford), 14(6):403-408.

26. Reig $M$, Mariño $Z$, Perelló $C$, Iñarrairaegui $M$, Ribeiro $A$ and
Lens S. (2016): Unexpected early tumor recurrence in patients with hepatitis $\mathrm{C}$ virus related hepatocellular carcinoma undergoing interferon-free therapy: a note of caution. J Hepatol., 65:719-726.

27. Singh S, Fujii $L$ and Ehman $R$. (2013): Decompansated liver cancer of chronic liver diseases. Clin Gastroenterol Hepatol., 11(12):157384.

28. Tatsumi A, Maekawa $S$ and Sato $M$. (2015): Liver stiffness measurement for risk assessment of hepatocellular carcinoma. Hepatol Res., 45(5):523532.

29. Yang JD, Mohamed EA, Abdel Aziz AO and Shousha HI. (2016): Characteristics, management, and outcomes of patients with hepatocellular carcinoma in Africa: a multicounty observational study from the Africa Liver Cancer Consortium. Lancet Gastroenterol Hepatol., 2(2):103-111.

30. Zacharakis G, Aleid $A$ and Aldossari KK. (2018): New and old biomarkers of hepatocellular carcinoma. Hepatoma Res., 4:65-73. 


\section{العلاقة بين درجة تصلب الكبلد وتطور سرطان الخلايا الكبلية للدى مرضى إلتهاب الكبد الوبائي المزمن}

محمد محمود الطواب، عادل عبد الفتاح الركيب، محمد كمال الثرقاويث*، احمد محمد ابو حسن

قسمي الباطنة العامة والأثعة التثخيصيةث*، كلية الطب، جامعة الأزهر

E-mail: $\underline{\text { meltwab88@gmail.com }}$

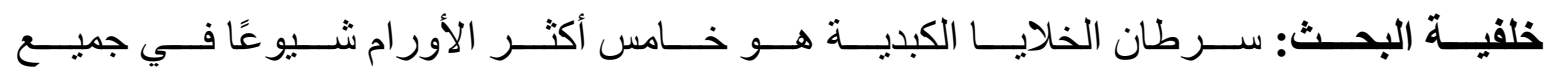

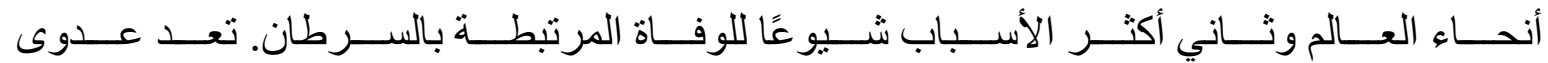

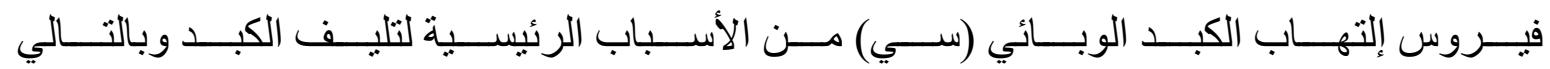

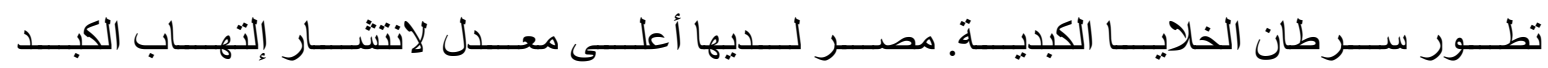

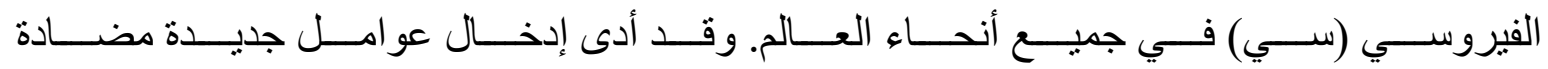

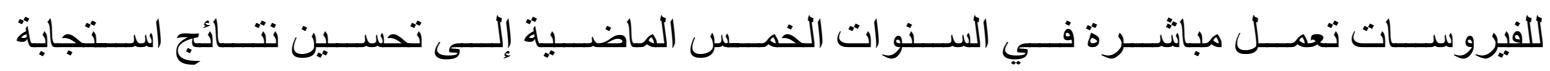

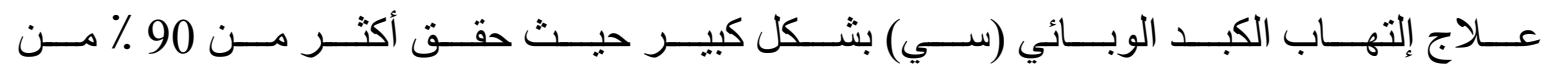

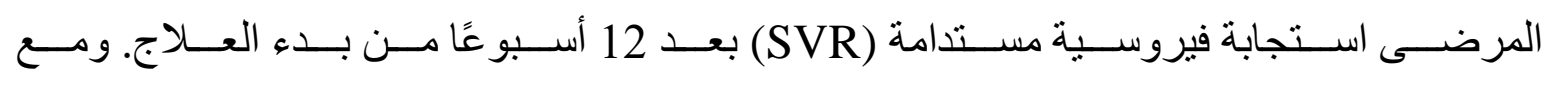

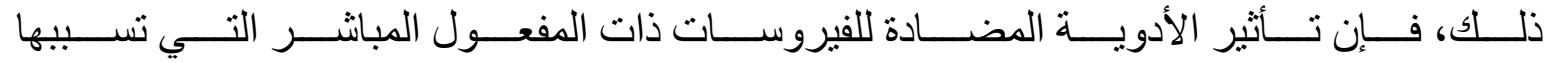

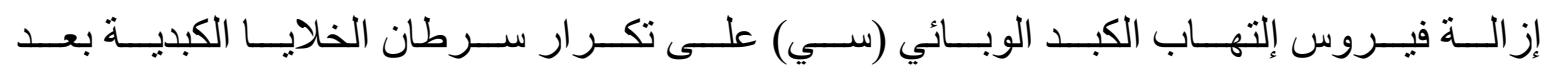
علاج سرطان الخلايا الكبدية قد برز كموضوع مثير للجدل.

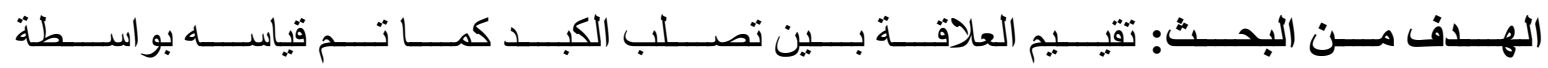

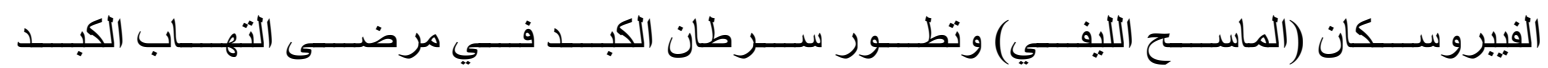
المزمن (سي).

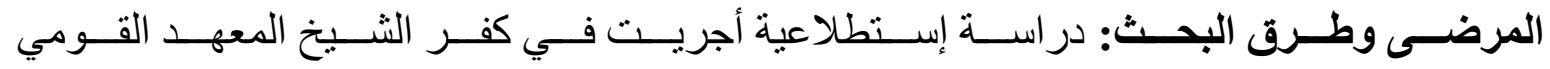

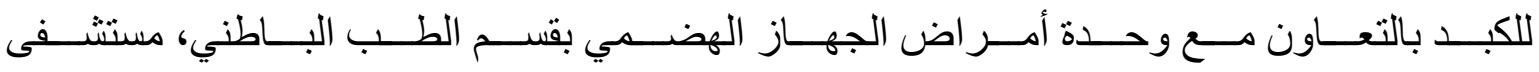

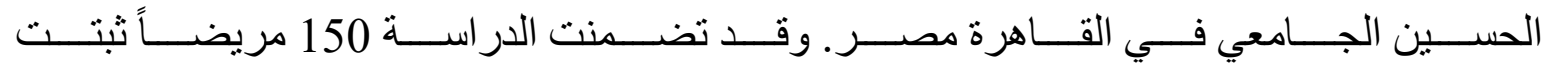

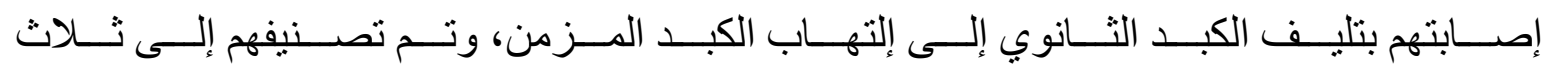

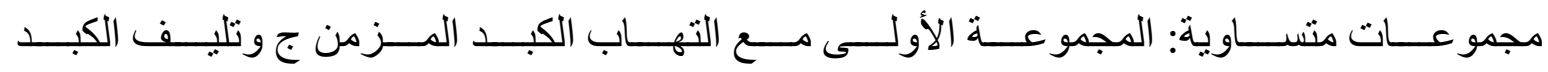

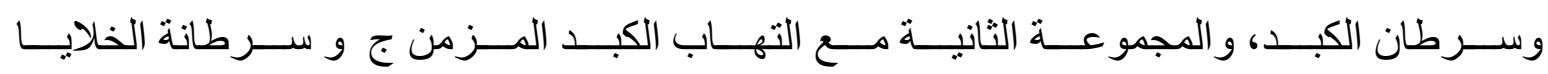




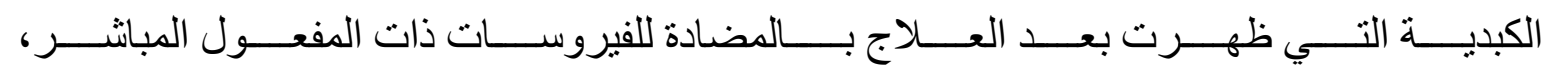

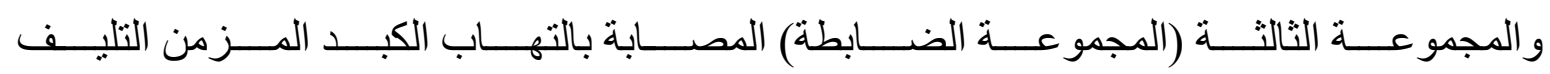
الكبدي و مع التهاب الكبد المزمن (سي) دون سرطان الكبد.

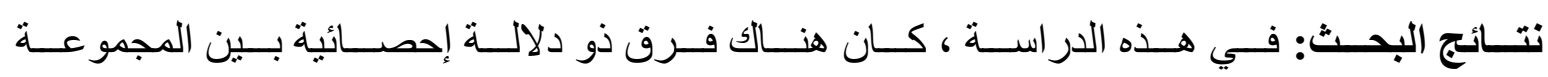

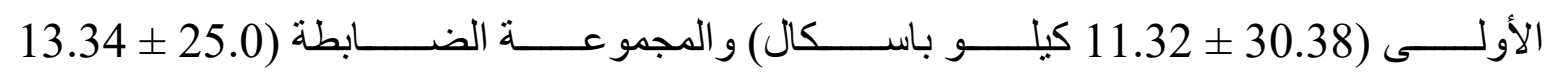

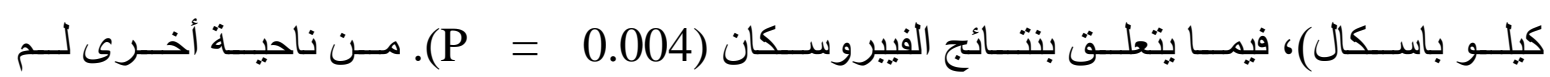

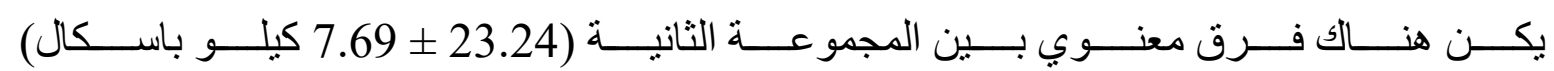
و المجموعة الضابطة بخصوص تصلب الكبد.

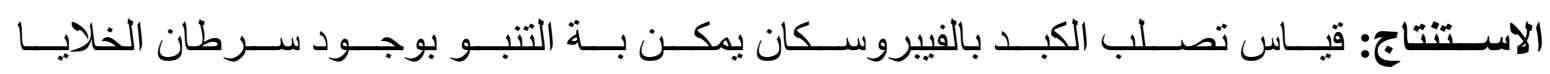

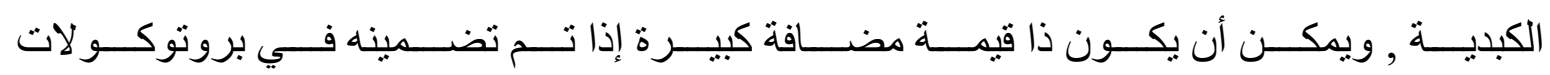

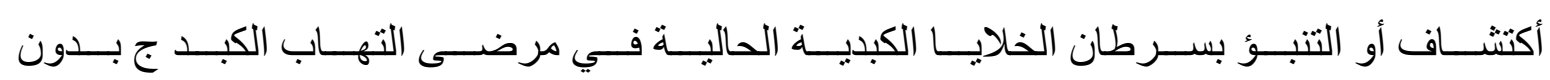
علاج.

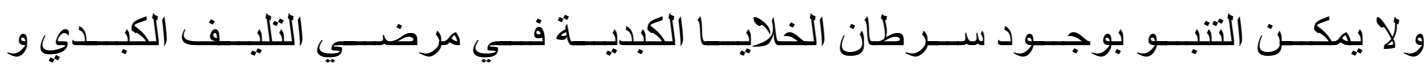

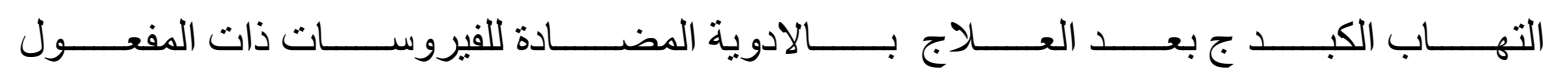

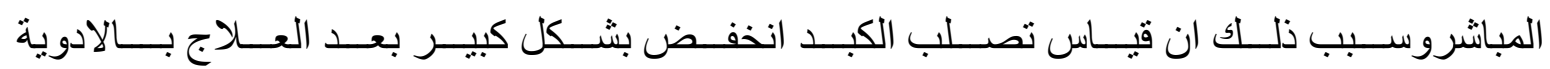

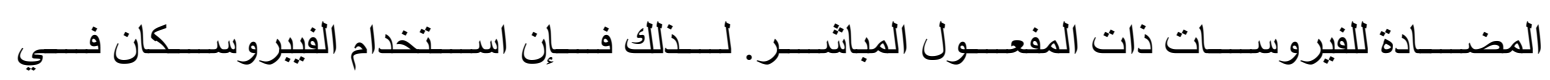
هؤ لاء المرضى سيكون مضلاً للتنبوء بوجود سرطان الكبد.

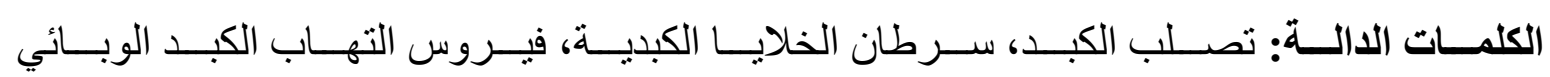
المزمن. 